\title{
Erratum to: Evaluating the Change in Medical Marijuana Dispensary Locations in Los Angeles Following the Passage of Local Legislation
}

\section{Crystal Thomas ${ }^{1} \cdot$ Bridget Freisthler $^{2}$}

\section{Erratum to: J Primary Prevent DOI 10.1007/s10935-017-0473-8}

The original version of article unfortunately contained a mistake. Reference Pacula, R. L., Powell, D., \& Heaton, P. (2013) is incorrect. The correct reference is given below.

Pacula, R. L., Powell, D., Heaton, P., \& Sevigny, E. L. (2015). Assessing the effects of medical marijuana laws on marijuana use: The devil is in the details. Journal of Policy Analysis and Management, 34(1), 7-31.

The online version of the original article can be found under doi:10.1007/s10935-017-0473-8.

Crystal Thomas

Thomasc@ucla.edu

Bridget Freisthler

Freisthler.19@osu.edu

1 Department of Social Welfare, UCLA Luskin School of Public Affairs, 3250 Public Affairs Building, Box 951656, Los Angeles, CA 90095, USA

2 College of Social Work, Ohio State University, 1947 College Road, Columbus, OH 43210, USA 